\title{
Scanning Electron Microscope Investigations on the Vaginal Epithelium of the Guinea Pig during the Estrous Cycle
}

\author{
Wolfgang KüHNEL and Andrés S. MENDOZA \\ Institut für Anatomie der Medizinischen Universität zu Lübeck, Lübeck, Federal Republic of Germany
}

Received January 18, 1992

\begin{abstract}
Summary. The present scanning electron microscope investigation describes the morphological changes occurring on the apical surface of the guinea pig vaginal epithelium during the estrous cycle. Dramatic changes can be observed at estrus in which the surface of the vaginal epithelium is covered by a distinct layer of mucous cells.
\end{abstract}

An especial feature of the guinea pig vaginal epithelium is the presence of mucous cells which show both differing maturation and distribution during the estrous cycle (RETTERER, 1892; LATASTE, 1893; StOCKARD and PapanicolaOU, 1917; Selle, 1922; Kelly, 1929; DurRani et al., 1985; Winterhager and KÜHNEL, 1985). They form a distinct layer above the keratinizing stratified squamous epithelium at estrus. This mucous layer is extruded during estrus followed by the keratinized cell layers (CROIX and FRANCHIMONT, 1975). Thus, the apical surface of the guinea pig vaginal epithelium in metestrus is composed of a different cell population than that of estrus. The aim of the present study was, therefore, to describe the morphological aspects of the apical surface of the vaginal epithelium during the estrous cycle using scanning electron microscopy.

\section{MATERIALS AND METHODS}

The vaginal epithelia of 12 guinea pigs (Pirbright white strain) were investigated. After controlling the stage of estrous cycle by vaginal smears (DURRANI et al., 1985) three animals per stage (diestrus, proestrus, estrus and metestrus) were anesthetized with sodium pentobarbitone $(0.24 \mathrm{mg} / \mathrm{g}$ body weight) and perfused through the heart according to MENDOZA and KÜH NEL (1987). Fixation was carried out with a solution composed of $2 \%$ glutaraldehyde and $0.6 \%$ paraformaldehyde in $0.06 \mathrm{M}$ sodium cacodylate buffer ( $\mathrm{pH} 7.35$ ) at room temperature. The vaginal epithelium was then excised and immersed in the same fixative for several hours at $4^{\circ} \mathrm{C}$. Following rinsing in $0.2 \mathrm{M}$ sodium cacodylate buffer, the samples were postfixed with $1 \%$ osmium tetroxide in $0.2 \mathrm{M}$ sodium cacodylate buffer for $3 \mathrm{~h}$. After rinsing in $2.4 \% \mathrm{NaCl}$ the vaginal epithelium was processed for scanning electron microscopy as follows. Samples were dehydrated in alcohol, critical point dried, coated with platin (the thickness of the metal coat was less than $100 \mathrm{~nm}$ ) in a Polaron E 5100 ion coater and examined with a Philips 505 scanning electron microscope at $25 \mathrm{kV}$.

\section{RESULTS}

As reported by other authors (CROIX and FRANCHIMONT, 1975; OHNISHI et al., 1986) the duration of the estrous cycle in the guinea pig fluctuates between 14 and 16 days (Proestrus $=1-1.5$ days. Estrus $=8-24 \mathrm{~h}$. Metestrus $=1-1.5$ days. Diestrus 13-15 days).

The following description emphazises the morphological aspects of the apical surface of the vaginal epithelium during the estrous cycle.

Diestrus: The cells covering the apical surface of the vagina show a regular form. They are mainly polygonal or elongated and are provided with numerous short, often blunt and stublike microvilli on their free luminal surface (Fig. 1). 

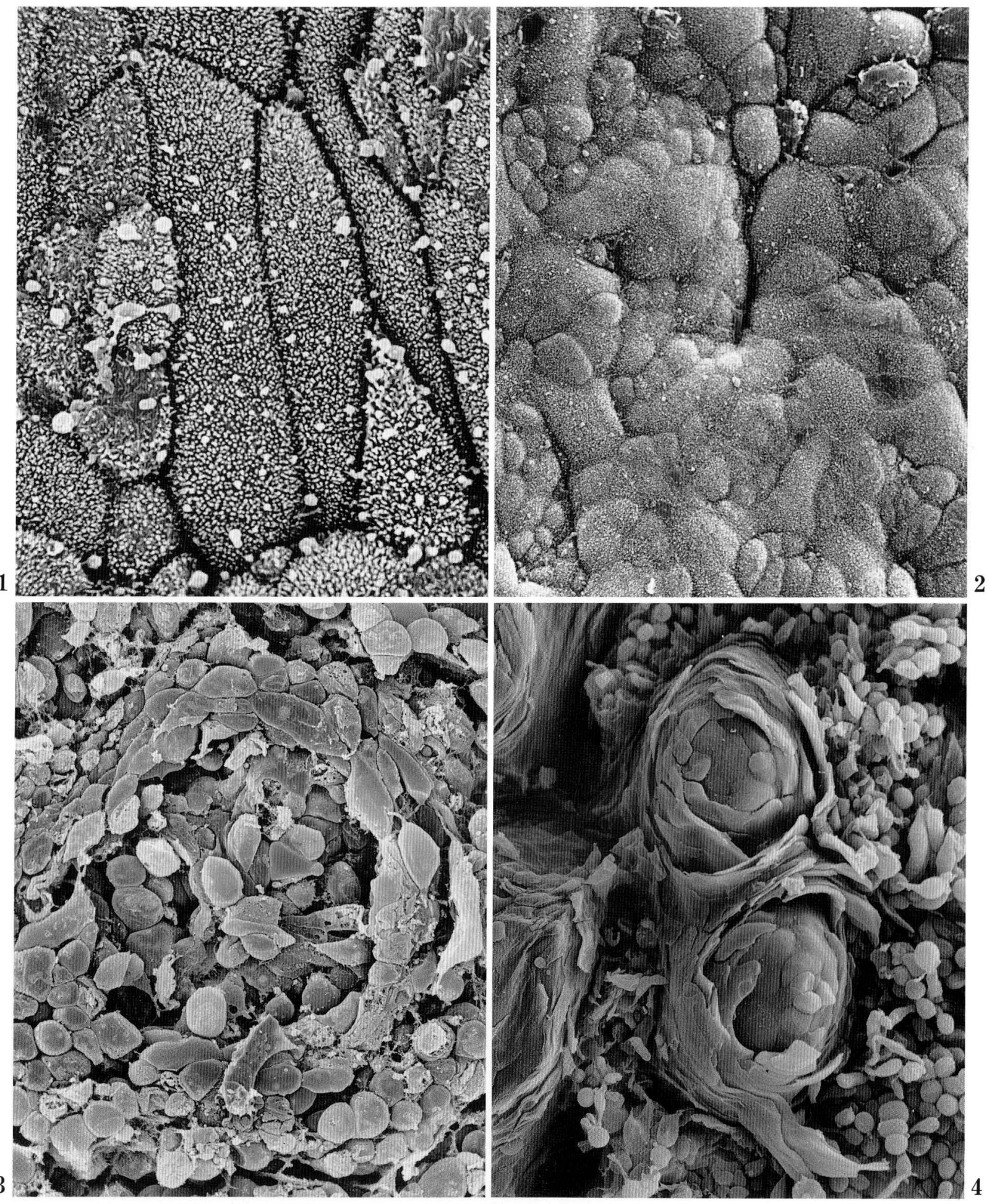

Fig. 1. Apical surface of the vaginal epithelium in diestrus. Note the polygonal form of the cells and the numerous stublike microvilli on the free surface. $\times 4,600$

Fig. 2. Apical surface of the vaginal epithelium in proestrus. Note the irregular form of the cells and the different sizes of their apical protrusions. $\times 1,250$

Figs. 3 and 4. Different morphological aspects of the surface of the vaginal epithelium in estrus. Fig. 3 shows mucous cells covering the surface of the vagina. Note the artichoke-like structures formed by the keratinized epithelial cells (Fig. 4). Fig. 3: $\times 525$, Fig. 4: $\times 355$ 

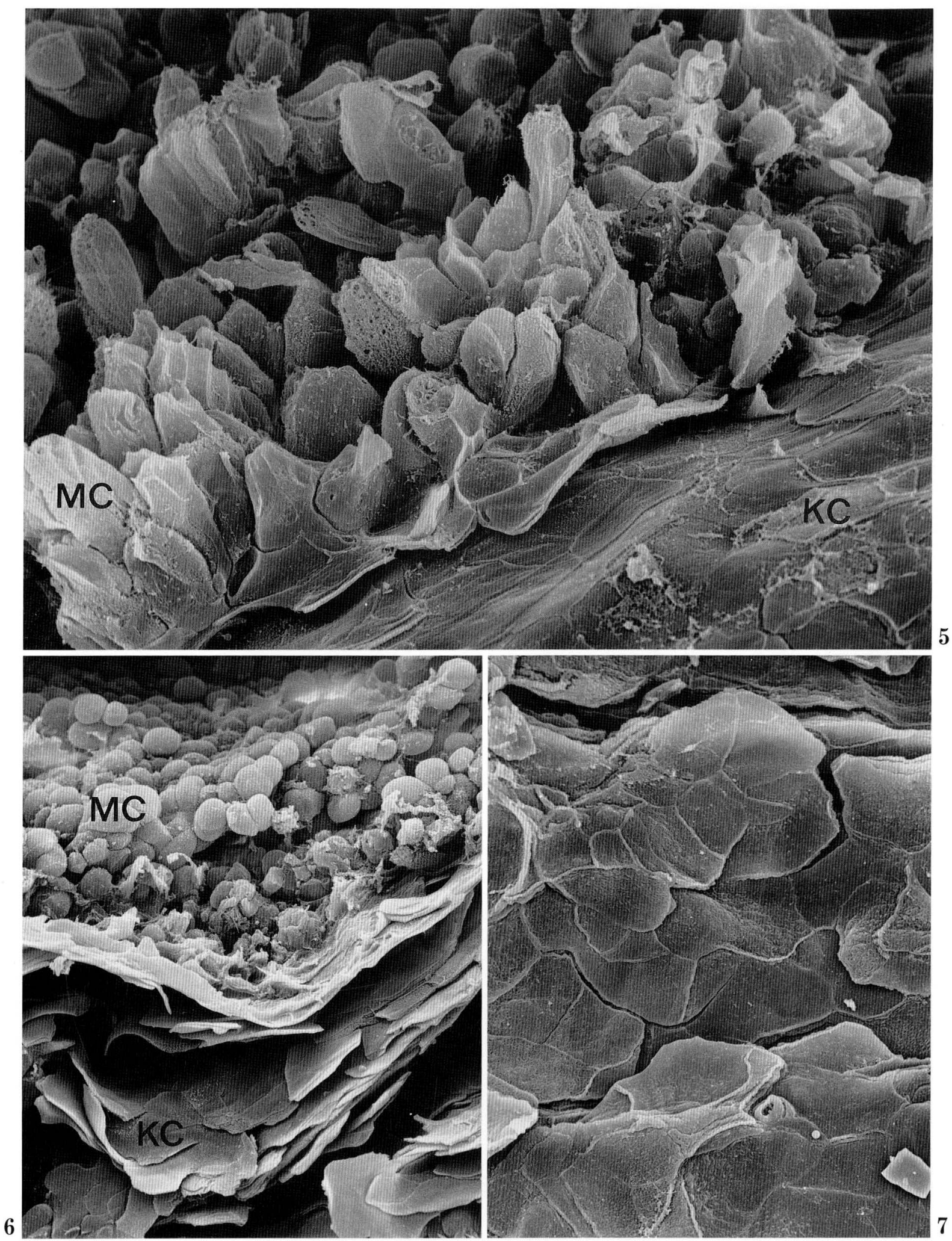

Figs. 5-7. Vaginal epithelium in estrus. Fig. 5. Mucous cells $(M C)$ and keratinized cells $(K C)$ are seen covering the surface of the vagina. $\times 1,200$. Fig. 6 . Cut end of a preparation showing numerous layers of keratinized cells $(K C)$ and the mucous cells $(M C)$ above them. $\times 625$. Fig. 7. Flattened keratinized cells are observed covering the apical surface of the vagina. $\times 1,250$. 

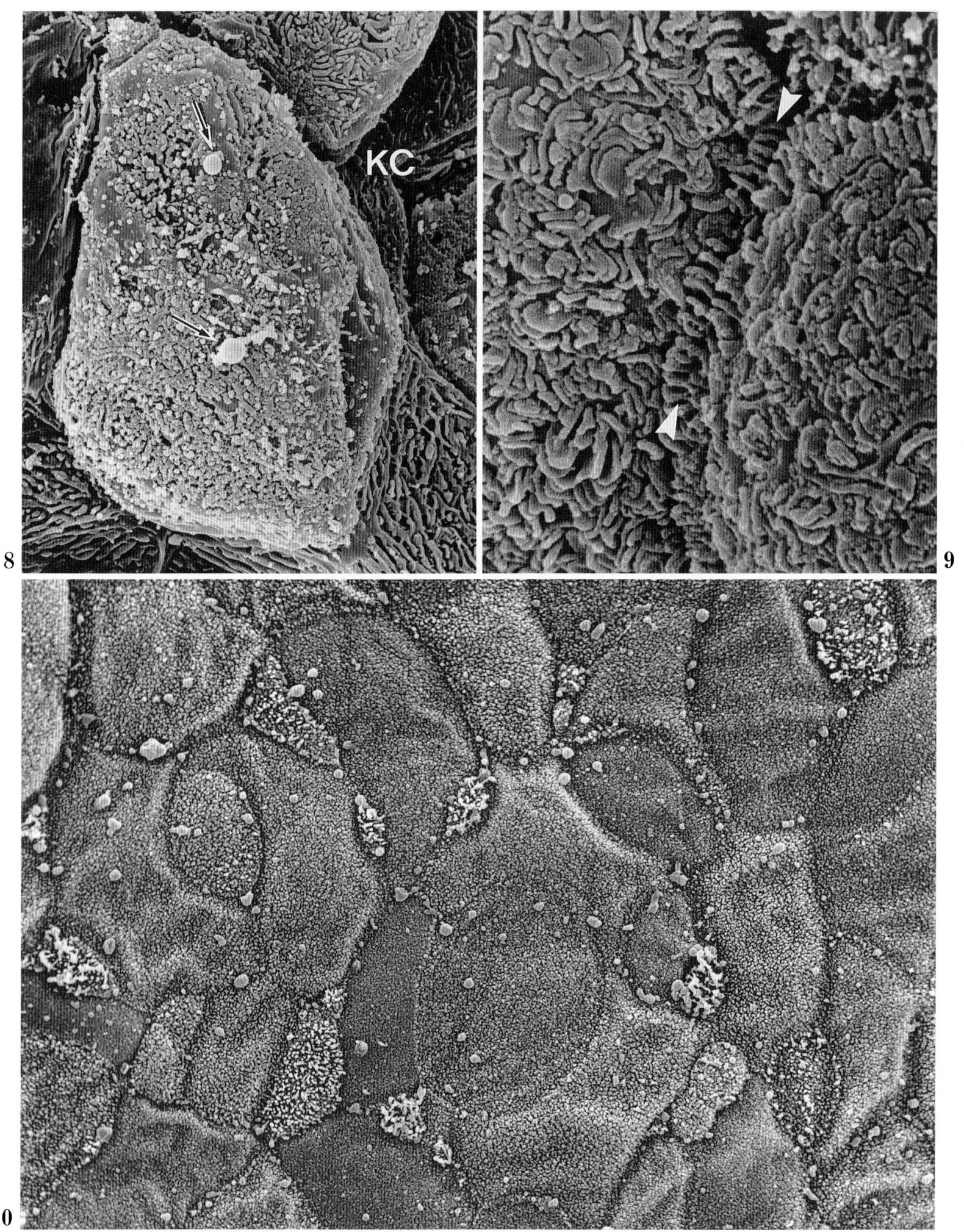

Figs. 8 and 9. Vaginal epithelium in estrus. Note the microridges and microplicae at the surface of the keratinized cells $(K C)$. Arrows in Fig. 8 indicate vesicles and arrowheads in Fig. 9 indicate interdigitations between keratinized cells. Fig. 8: $\times 4,360$, Fig. 9: $\times 13,000$

Fig. 10. Apical surface of the vaginal epithelium in metestrus. Note the large and polygonal cells with numerous short microvilli. $\times 2,400$ 
Proestrus: The relatively quiet and regular appearance of the vaginal epithelium during diestrus becomes restless at the proestrus stage. The form of the cells varies considerably, and the free luminal surface looks like irregular cobblestones and shows protrusions of different sizes (Fig. 2). Numerous short and stublike microvilli, as in diestrus, are also observed.

Estrus: The morphological changes in the apical surface of the guinea pig vaginal epithelium become more evident at this stage of the estrous cycle. Mucous cells can be seen covering the surface of the vagina (Figs. 3-6). These cells, with different necrotical debris, rest upon cornified cell layers (Figs. 5, 6). As mentioned before, these mucous cells are extruded into the lumen of the vagina during this stage, followed by desquamation of the underlying flattened keratinized cells. Thus, it is not surprising that the surface of the vagina at this stage is covered in part by mucous cells (Fig. 3) or by keratinized epithelial cells (Fig. 5, 7). Sometimes keratinized cells form artichoke-like structures which protrude into the lumen of the vagina (Fig. 4). Many layers of keratinized cells can be observed at the cut end of a preparation (Fig. 6). The plasma membrane of these cells shows a characteristic pattern of microplicae or short microridges (Figs. 8, 9). Some vesicles, probably cell detritus, can also be observed at the plasma membrane of keratinized cells located most apically (Fig. 8).

Metestrus: After the desquamation of the keratinized epithelial cells during late estrus, the surface of the vagina is covered at metestrus stage by the cells of the stratum spinosum. These cells are large, polygonal and provided with numerous microvilli on their free surface (Fig. 10). They begin a mucifying process which concludes with a necrotic one at the estrus stage of the next cycle.

\section{DISCUSSION}

The different morphological appearance of the surface of the vaginal epithelium of mature female guinea pigs during the estrous cycle as seen in the present study is due to: 1 ) the different cell populations covering the vagina at estrus and metestrus; and 2) a mucifying process which the apical cells undergo between the last metestrus and the next estrus stage. The mucifying process occurs during the luteal phase in which the plasma level of progesterone increases, reaching a maximum at the 12th day of the cycle, or at late diestrus (CROIX and FranCHIMONT, 1975), whereas the necrotic process of these mucous cells is accompanied by the keratinization of the underlying cell layers occurring during proestrus and preovulatory estrus, when estradiol plasma level reaches its maximum (CROIX and FRANCHIMONT, 1975).

Our SEM observations are in accord with the findings in vaginal smears, which distinguish five stages in the estrous cycle, for which each is represented by a different smear picture; they are also in accord with examinations of cross-sections of the vagina. Cross-sections show that the vaginal membrane consists of an epithelium composed of up to three layers, depending on the phase of the cycle: the mucous layer (superficial), the keratin layer, and next to the lamina propria - the less mature squamous epithelium. In early diestrus, an immature stratified squamous epithelium overlies fibrous stroma of the lamina propria, and by late diestrus many mucous cells have developed in the stratified squamous epithelium. In proestrus and estrus the epithelium is composed of a thick layer of mucous cells beneath which is a thick layer of immature (keratinizing) stratified squamous epithelium, whereas in metestrus a mature stratified squamous epithelium overlies the lamina propria.

\section{REFERENCES}

Croix, D. and P. Franchimont: Changes in the serum levels of the gonadotrophins. Progesterone and estradiol during the estrous cycle of the guinea pig. Neuroendocrinology 19: 1-11 (1975).

Durrani, M. J., A. Kusai, N. F. H. Ho, J. L. Fox and W. I. Higuchi.: Topical vaginal drug delivery in the guinea pig. I. Effect of estrous cycle on the vaginal membrane permeability of vidarabine. Int. J. Pharm. 24: 209-218 (1985).

KeLLY, G. L.: The histological transformations in the vaginal epithelium of the guinea pig. Amer. J. Anat. 43: 247-288 (1929).

Lataste, F.: Rhythme vaginal des mammiféres. Mem. Soc. Biol. (Paris) 45: 135 (1893).

Mendoza, A. S. and W. KüHnel: Morphological evidence for a direct innervation of the mouse vomeronasal glands. Cell Tiss. Res. 247: 457-459 (1987).

OhNishi, R., E. Winterhager and W. Kühnel: Das Oberflächenrelief der Meerschweinchen-Vagina im Oestrus. Z. Mikrosk.-Anat. Forsch. 100: 372-378 (1986).

RetTerer, E.: Evolution de l'epithélium du vagin. C. R. Soc. Biol. (Paris) 44: 566 (1892).

Selle, R. M.: Changes in the vaginal epithelium of the guinea pig during the oestrus cycle. Amer. J. Anat. 30: 429-449 (1922). 
Stockard, C. R. and G. N. Papanicolaou : The existence of a typical oestrus cycle in the guinea pig-with a study of its histological and physiological changes. Amer. J. Anat. 22: 225-283 (1917).

WINTERHAGER, E. and W. KüHNEL: Diffusion barriers in the vaginal epithelium during the estrous cycle in the guinea pigs. Cell Tiss. Res. 241: 325-331 (1985).
Prof. Dr. Wolfgang KÜHNEL

Institut für Anatomie

der Medizinischen Universität zu Lübeck

Ratzeburger Allee 160

D-2400 Lübeck 1

Federal Republic of Germany 